\title{
Sauromatum venosum (Dryand. ex Aiton) Kunth (Araceae : Areae): an addition to the Flora of Arunachal Pradesh in Eastern Himalaya, India
}

\author{
Atek Nangkar and Hui Tag ${ }^{1}$ \\ Plant Systematics and Ethanobotanical Research Laboratory, Department of Botany, Rajiv Gandhi \\ University, Rono Hills, Doimukh-791112, Arunachal Pradesh, India. \\ ${ }^{1}$ Crossponding author, e-mail: huitag2008rgu@gmail.com
}

[Received 03.05.2019; Revised 12.06.2019; Accepted 21.06.2019; Published 30.06.2019]

\begin{abstract}
Sauromatum venosum (Dryand. ex Aiton) Kunth (Araceae : Areae) is first recorded from Arunachal Pradesh, in Indian Eastern Himalaya. A detailed taxonomic description, drawing and living color photographic illustration, GPS location, are provided along with key to species of Sauromatum in Arunachal Pradesh.
\end{abstract}

Key words: Sauromatum venosum, New record, Arunachal Pradesh, Eastern Himalaya

\section{INTRODUCTION}

The genus Sauromatum (Araceae : Areae) was established by Heinrich Wilhelm Schott in 1832 and S. pedatum (Link \& Otto) Schott (basionym Arum pedatum Link \& Otto) and $S$. guttatum (Aiton) Schott (basionym Arum guttatum Aiton) were included in it. Genus Arum L., Biarum Schott and Typhonium Schott are placed under Subtribe Euaroideae. Genus Sauromatum was separated from Arum and Biarum by having groups of staminodes below male flowers and from Typhonium by connate spathe base, two ovules in overy, leaf appearing after the inflorescence, leaf pedate and very short peduncle (Hetterscheid \& Boyce 2000; Cusimano et al. 2010). In a preliminary phylogenetic studies of Typhonium and Sauromatum species, Hetterscheid and Boyce (2000) merged both genera into Typhonium. Latter on, Cusimano et al. (2010) retained Sauromatum and Typhonium as separate genus in accordance with the study of chloroplast DNA sequences. The genus Sauromatum is consists of 09 species as recorded in www.theplantlist.org. In recent years, Talukdar et al. (2014) and Nangkar and Tag (2018) published two new species for the genus but are yet to be included in The Plant List. This genus is distributed in South East Asia from China to Indonesia, Nepal, Bhutan, India, Bangladesh, Myanmar, Thailand, Vietnam and Cambodia. The four species reported in India are Sauromatum brevipes (Hook.f.) N.E.Brown, Sauromatum diversifolium (Wall. ex Schott) Cusimano \& Hett., Sauromatum meghalayense D.K.Roy, A.D.Talukdar, B.K.Sinha \& M.Dutta Choudhury, S. venosum (Dryand. ex Aiton) Kunth (Talukdar et al. 2014) and Sauromatum nangkarense A. Nangkar \& H. Tag (2018).

During our field exploration from 2014 to 2018 at Anini in Dibang Valley district of Arunachal Pradesh an aroid plant was collected with inflorescence (flowers and fruits) from the moist floor of an evergreen forest near a stream. The morphological characters of the plant including pedatisect, pale green leaves, spathe tube convolute, staminodes clavate, and with persistent spathe-tube revealed that it is a species of the genus Sauromatum. The 


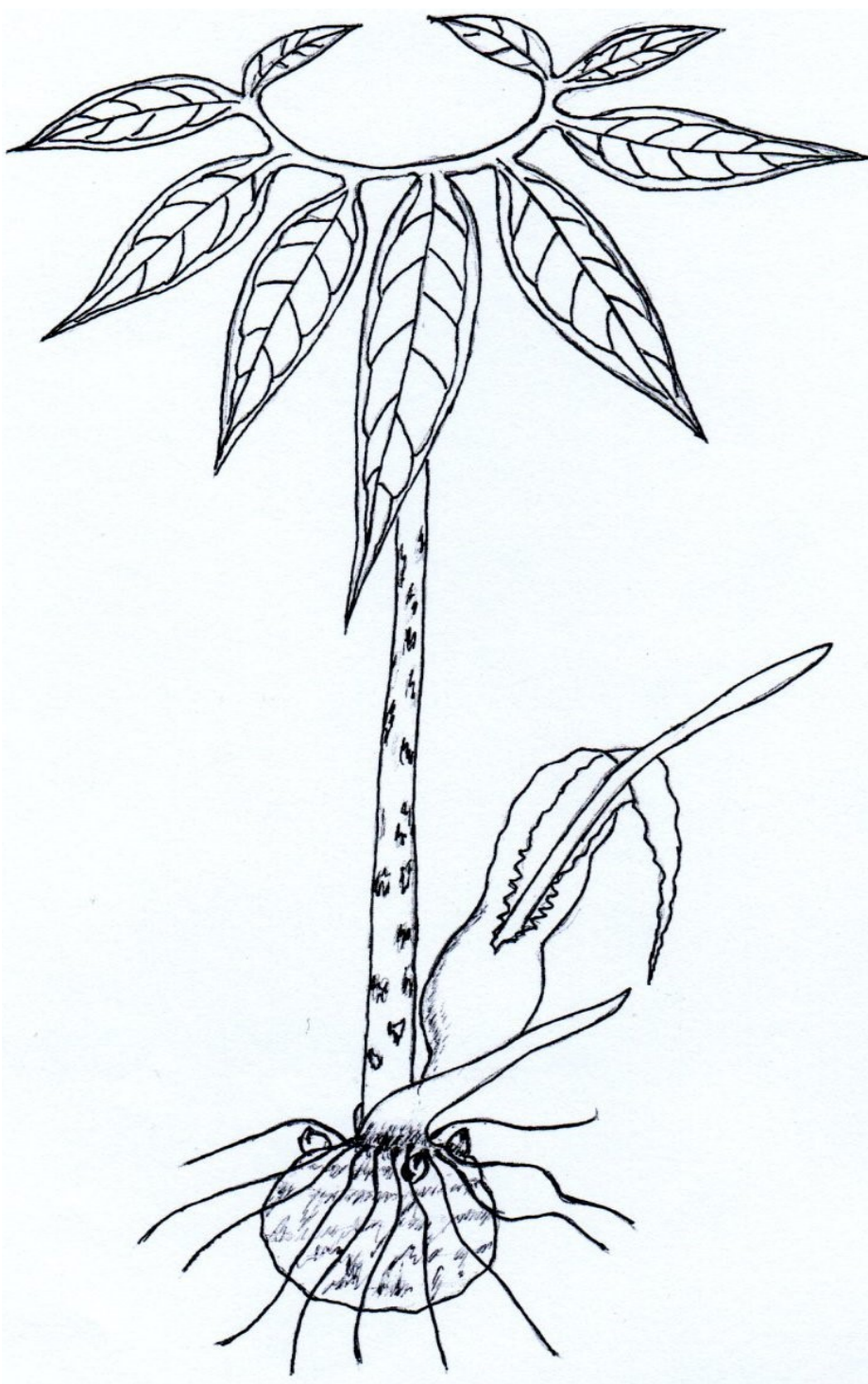

A

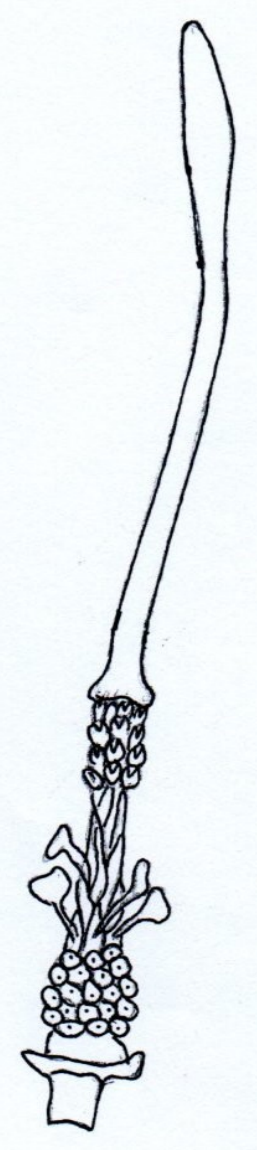

B

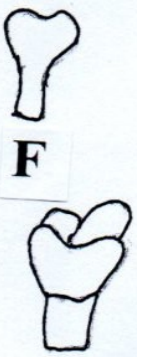

$\mathbf{G}$

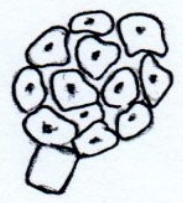

C

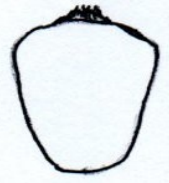

D

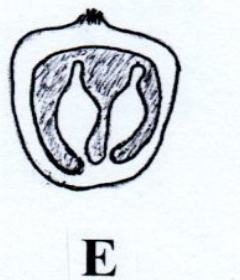

Figure 1.. Sauromatum venosum (Aiton) Kunth. A. Flowering plant; B. Spadix; C. Fruit; D. Ovary; E. L.s. of ovary; F. Staminode; G. Synandrium 


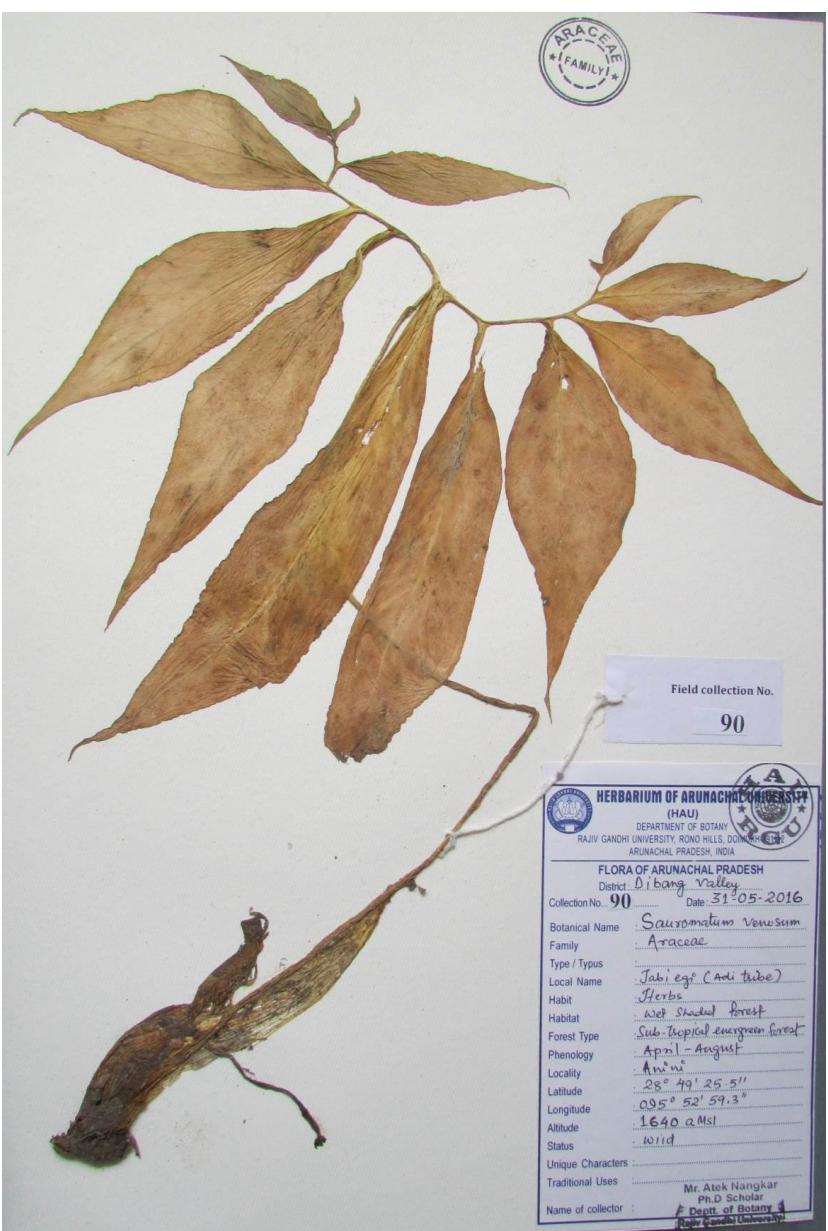

Figure 2. Voucher specimen, Atek Nangkar 90. critical analysis of the specimens and literature (Hooker 1893; Hetterscheid \& Boyce 2000; Hetterscheid et al. 2001; Cusimano et al. 2010; Heng \& Hetterscheid 2010; Talukdar et al. 2014; Nangkar \& Tag 2018), the plant was identified as Sauromatum venosum (Aiton) Kunth, a hitherto unknown species from Arunachal Pradesh. The Arunachal specimens of this plant are morphologically slightly different from the specimens from other parts of world including Western Ghats in having taller pseudostem, longer pink appendix, stipitate spadix. However, these differences are not counted as of much taxonomic significance. Differences of Sauromatum venosum with our previously reported $S$. nangkarense is presented in Table 1.

In this publication, Sauromatum venosum is recorded as an addition to the Flora of Arunachal Pradesh. A detailed description and living color photographic illustration has been provided.

Table 1. Distinguishing morphological characters of S.nangkarense and S. venosum

\begin{tabular}{|l|l|l|}
\hline Characters & Sauromatum nangkarense & Sauromatum venosum \\
\hline Leaf blade & $\begin{array}{l}\text { Leaflets } 5-7, \text { broad, } 7-20 \mathrm{~cm} \\
\text { long, } 3-10 \mathrm{~cm} \text { in diameter }\end{array}$ & $\begin{array}{l}\text { Leaflets } 9-17, \text { narrow, } 7-33 \mathrm{~cm} \\
\text { long, } 2-8.7 \mathrm{~cm} \text { diameter }\end{array}$ \\
\hline Spathe tube & Convolute, green to purple & Connate, dark purple \\
\hline Spadix & Sessile & Shortly stipitate \\
\hline Appendix & $\begin{array}{l}\text { Short, white, somewhat cone } \\
\text { shaped, } 7 \mathrm{~cm} \text { long }\end{array}$ & Long, pinkish, $18-21 \mathrm{~cm}$ long \\
\hline Staminodes & Pink, two types, curved downward & Yellow, one type, radiate or upward \\
\hline & & \\
\hline
\end{tabular}

\section{MATERIALS AND METHODS}

The collection, pressing and preparation of herbarium specimens in accordance to standard herbarium technique (Jain \& Rao 1977). Description of morphological characters and taxonomic measurement of plant are based on living materials, Photograph with Cannon Power Shot SX500 IS. The voucher specimen will be deposited in ASSAM Herbarium. 
Atek Nangkar \& Hui Tag 195

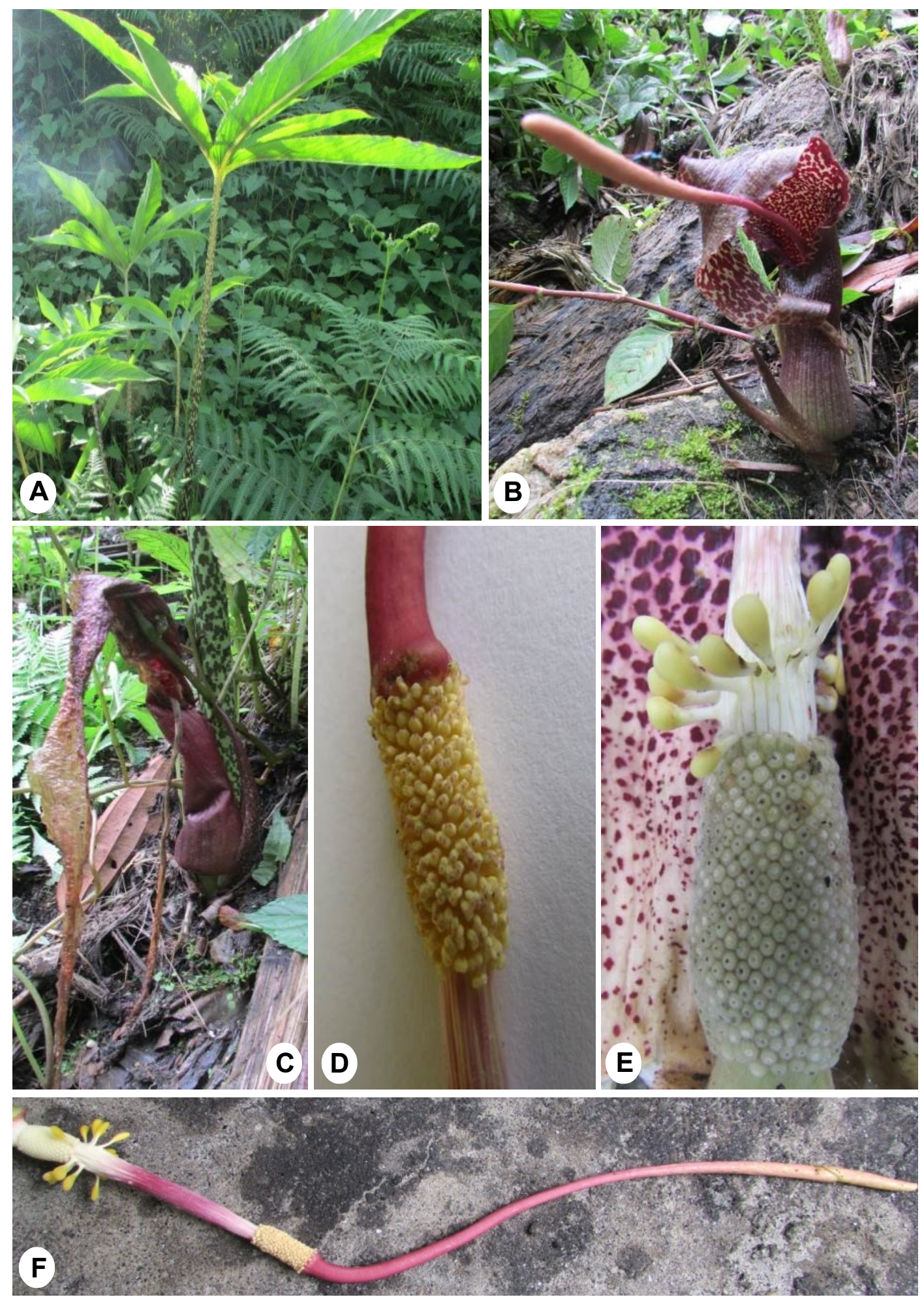

PLATE I. Sauromatum venosum (Aiton) Kunth: A. plant habitat; B. Close view of inflorescence; C. Old inflorescence; D. Male flowers (synandrium); E. Female flowers; F. Close view of spadix 


\section{TAXONOMIC TREATMENT}

Sauromatum venosum (Aiton) Kunth, Enum. Pl. 3: 281. 1841. [Figures 1 \& 2; PLATE I] Arum venosum Aiton, Hortus Kew. 3: 315. 1789

Herbs; tuber depressed globose, $2.5-4 \mathrm{~cm}$ high and $0.5 \mathrm{~cm}$ wide, producing $2-3$ offsets annually. Root few, white. Leaves solitary, ppedate, pale green. Cataphylls 4-5, 3 cataphylls common for both inflorescence and leaf, one separate cataphyll for leaf, mottled with green and purple or purple spots, lanceolate, acute, $5-10 \mathrm{~cm}$ long, $2-3.5 \mathrm{~cm}$ wide. Petiole $28-85 \mathrm{~cm}$ heigh. Mottled, yellowish green, dark green with rounded purplish brown spots; leaflets $9-17$, gradually smaller toward distal end of rachis, middle leaflet large, oblong, oblanceolate, $33 \times 8.7 \mathrm{~cm}, 2^{\text {nd }}$ larger leaflets, $30 . \times 7.7 \mathrm{~cm}$, smallest leaflets 7 x $2 \mathrm{~cm}$, lateral leaflets elliptic, acute to acuminate. Inflorescence solitary, appearing before emergence of leaf; peduncle greenish white, $2.3-3.2 \mathrm{~cm}$ long, may continue elongating during fruit development. Spathe tuber, slightly constricted, $10-14 \mathrm{~cm}$ long, 5 $-8 \mathrm{~cm}$ wide, dark purple outside without spots, inside rich dark purple at distal end, intermingled with purple and yellow ellipsoid spots; limb spreading, $23 \mathrm{~cm}$ long, $6.7 \mathrm{~cm}$ wide at expanded parts, acuminate, prominent dark purple spots mixed with light yellow irregular-lanceolate spots . Spadix slightly shorter than or equal to spathe; stipe $1-1.8$ $\mathrm{cm}$ long, $2 \mathrm{~cm}$ wide. Female zone $1.5-2.5 \times 1-1.5 \mathrm{~cm}$; central part expanded, drumshaped, both ends tapering, subcylindric; ovary white, obovoid; $1^{\text {st }}$ sterile zone $5-7.5$ $\mathrm{cm}$ long, proximal, $1-1.5 \mathrm{~cm}$ long, whitish, sparsely covered with clavate staminodes with groove, $6 \mathrm{~cm}$ long, and naked, pale purple-pink; staminodes yellow, clavate, $0.5-1 \mathrm{~cm}$; male zone white to yellow, $1.5-2 \mathrm{~cm}$ long, $0.5-0.7 \mathrm{~cm}$ wide, cylindrical; stamens white to yellow, pink at tip; $2^{\text {nd }}$ sterile zone (appendix) pink, $18-21 \mathrm{~cm}$ long, $0.2-0.4 \mathrm{~cm}$ wide, glabrous, base expanded near male zone, flat like elephant foot, terete, obtuse, erect. Berries sub-globose, crowded, bright purple, apex truncate.

Flowering \& Fruiting: May - August.

Specimen cited: INDIA: Arunachal Pradesh, Dibang Valley district, Anini, $1640 \mathrm{~m}$, Latitude $28^{\circ} 49^{\prime} 25.53 \mathrm{~N}$ and Longitude $095^{\circ} 52^{\prime} 59.33$ E, Atek Nangkar 90 HAU/AN, dated 31.05.2016 (ASSAM).

Distribution: Tropical Africa to China (Yunnan).

IUCN Conservation status: Least Concern (LC). The species was encountered in one locality at Anini of Dibang Valley district in Arunachal Pradesh. In India plant is reported from Western Ghats. Few plants were collected for ex-situ conservation and to examine the inflorescence and the plant is introduced in Botanical garden, Department of Botany, Rajiv Gandhi University but not growing well due to altitudinal and climatic differences.

\section{Acknowledgments}

The first author is grateful to the Coordinator CPEB-II, Rajiv Gandhi University, Dr. S.N. Sharma and co-coordinator Dr. Hui Tag for financial facilities and encouragement.

\section{LITERATURE CITED}

Cusimano, N.; Barrett, M.D.; Hetterscheid, W.L.A. \& Renner, S. 2010. A phylogeny of the Areae (Araceae) implies that Typhonium, Sauromatum, and the Australian species of Typhonium are distinct clades. Taxon 59(2): $439-447$. 
Heng, L. \& Hetterscheid, W.L.A. 2010. Sauromatum Schott. In: Wu, Z.Y.; Raven, P.H. \& Hong, D.Y. (eds.), Flora of China, vol. 23. Science Press, Beijing, and Missouri Botanical Garden Press, St. Louis. Pp. 36 - 39.

Hetterscheid, W.L.A. \& Boyce, P.C. 2000. A reclassification of Sauromatum Schott and new species of Typhonium Schott (Araceae). Aroideana 23: 48 - 55.

Hetterscheid, W.L.A.; Sookchaloem, D. \& Murata, J. 2001. Typhonium (Araceae) of Thailand: New Species and a Revised Key. Aroideana 24: 30 - 55.

Hooker, J.D. 1893. Aroideae. In: The Flora of British India, vol. 6. L. Reeve and Co., London. Pp. $490-556$.

Nangkar, A. \& Tag, H. 2018. Sauromatum nangkarense (Araceae; tribe: Areae), a new species from Arunachal pradesh, India. Pleione 12 (1): 87 - 93.

Jain, S.K. \& Rao, R.R. 1977. A Handbook of Field and Herbarium Methods. Today \& Tomorrow's Printer Publisher, New Delhi.

Talukdar, A.D.; Roy, D.K.; Sinha, B.K. \& Choudhury, M.D. 2014. Sauromatum meghalayense (Araceae; Tribe: Areae), a new species from Meghalaya, India. NeBIO 5(3): $1-3$.

The Plant List 2015. Version 1.1: www.theplantlist.org 